\title{
Histopathology of Ceriantheopsis americanus (Cnidaria: Ceriantharia) exposed to Black Rock Harbor dredge spoils in Long Island Sound
}

\author{
Esther C. Peters* ${ }^{*}$ Paul P. Yevich** \\ Environmental Research Laboratory, US Environmental Protection Agency, Narragansett, Rhode Island 02882, USA
}

\begin{abstract}
Over 500 specimens of the cerianthid anthozoan Ceriantheopsis americanus (Verrill 1864) were collected from central Long Island Sound between January 1982 and October 1984, and processed for histopathological examination with light microscopy. The collection stations included a control area and 3 areas located 200,400, and $1000 \mathrm{~m}$ east of the primary discharge of dredge spoils removed from Black Rock Harbor, Bridgeport, Connecticut $\left(73^{\circ} 13^{\prime \prime} \mathrm{W}, 41^{\circ} 9^{\prime \prime} \mathrm{N}\right)$. C. americanus collected prior to the dumping of spoil were generally in good to excellent condition, with the only notable lesions associated with the appearance of an unidentified microparasite which caused vacuolation and necrosis of the lobes of the mesenterial filaments. Specimens collected from the control, 1000E (1000 m east), and 400E stations following the completion of spoil discharge in May 1983 continued to exhibit fair to excellent health, with microparasite infections highest in the summer and fall. Specimens from the 200E station were in poor health in June 1983, with accumulations of cellular debris and necrosis evident in all areas of the body, although microparasites were absent. In particular, the epidermis was vacuolated, with erosion and loss of mucous secretory cells and ptychocysts, indicating disruption of tube-formation by these anemones. C. americanus obtained 1 yr later from the $200 \mathrm{E}$ station showed marked improvement in condition.
\end{abstract}

\section{INTRODUCTION}

One of the burrowing anemone-like anthozoans, Ceriantheopsis (= Cerianthus, Carlgren 1912, p. 22, cited in Carlgren 1951, p. 389) americanus (Verrill 1864), is commonly found in soft mud and sand bottoms of bays and estuaries along the northeast coast of North America (Widerstein 1976). These organisms secrete and inhabit a tube (Frey 1970) composed of mucus and ptychocysts, a pleated-thread type of nematocyst found in its epidermis (Mariscal et al. 1977). C. americanus is nocturnal, spreading its tentacles after dark and retreating into its burrow during the day (Frey 1970). Studies on this and other cerianthids indicate that these organisms are suspension and surface deposit feeders,

\footnotetext{
- Present address: Registry of Tumors in Lower Animals, National Museum of Natural History, Smithsonian Institution Washington, D.C. 20560, USA.

- Present address: Science Applications International Corporation, c/o US Environmental Protection Agency, Narragansett, Rhode Island 02882, USA
}

utilizing particulate matter and minute crustaceans, worms, and larvae of other species. Their feeding activities may affect the abundance and distribution of benthic fauna in an area (Carioccolo \& Steimle 1983, Eleftheriou \& Basford 1983).

Ceriantheopsis americanus has also been collected in surveys of polluted waters, including the New York Bight apex and Deepwater Dumpsite 106 in the MidAtlantic Bight (Pearce 1972, Pearce et al. 1976, Pearson \& Rosenberg 1978, Caracciolo \& Steimle 1983), often near the perimeters of polluted zones. Its presence and distribution in these areas suggest that this anthozoan is either susceptible, resistant or adaptable to a variety of pollutants and changes in water quality. However, there have not been any studies examining the acute effects of pollutant exposure on these organisms.

During a 4 yr survey of benthos response and recruitment to a dumpsite in Long Island Sound (Interagency Field Verification of Testing and Predictive Methodologies for Dredged Material Disposal Alternatives Program [Field Verification Program = FVP], sponsored by the US Army Corps of Engineers), Ceriantheopsis 
americanus were collected from selected sites before and after disposal of dredge spoils from Black Rock Harbor, Bridgeport, Connecticut. The dredged material that was dumped was enriched in polynuclear aromatic hydrocarbons (conc. 17 to $9100 \mathrm{ng} \mathrm{g}^{-1}$ with mol. wt between 1 and 302) and their alkylated homologs (conc. 110 to $13000 \mathrm{ng} \mathrm{g}^{-1}$ for mol. wt 128 to 252 , measured as the sum of the alkyl homologs between $\mathrm{C}-1$ and $\mathrm{C}-4$ ), polychlorinated biphenyls (ca $6800 \mathrm{ng} \mathrm{g}^{-1}$ ), and metals, including zinc (1200 $\left.\mathrm{g} \mathrm{g}^{-1}\right)$, copper $\left(2380 \mu \mathrm{g} \mathrm{g}^{-1}\right)$, lead (380 $\mu \mathrm{g} \mathrm{g}^{-1}$ cadmium (23 $\left.\mu \mathrm{g} \mathrm{g}^{-1}\right)$, chromium $(1430 \mu \mathrm{g}$ $\left.\mathrm{g}^{-1}\right)$, nickel $\left(140 \mu \mathrm{g} \mathrm{g}^{-1}\right)$, and mercury $\left(1.7 \mu \mathrm{g} \mathrm{g}^{-1}\right)$ (Rogerson et al. 1985). We report here on histopathological examinations of cerianthid tissues.

\section{SITE DESCRIPTION}

The FVP center dump site 'ground zero' (CNTR) at $41^{\circ} 9.4^{\prime \prime} \mathrm{N}, 72^{\circ} 51.7^{\prime \prime} \mathrm{W}$ was located within a previously designated disposal area in central Long Island Sound (CLIS). This site was selected for minimal contamination from other sources during the study, including relic or ongoing disposal operations (Yevich et al. 1987). The physical, chemical and biological nature of the disposal site was described by Scott et al. (1987). For this histopathology study, collections of anemones were made at stations located 200, 400 and 1000 m east (200E, 400E, $1000 \mathrm{E}$ ) of the discharge at CNTR, along the primary axis of current flow in the Sound. The control station (REFS) was ca $3 \mathrm{~km}$ south-southwest of the southern perimeter of the FVP site, over $1 \mathrm{~km}$ outside of the CLIS area. Water depth at all stations was ca $20 \mathrm{~m}$. Anemones were obtained from 3 stations (REFS, 1000E, 400E) prior to dredge spoil disposal. The 200E station was not included in this particular pre-exposure FVP sampling schedule (e. g. Pesch et al. 1985). Following the release of dredged material at the FVP CNTR in May 1983, anemones were collected from the REFS, 1000E, 400E and $200 \mathrm{E}$ stations once each month for $4 \mathrm{mo}$, then seasonally thereafter.

\section{METHODS*}

Specimens were obtained with a Smith-Maclntyre grab sampler $\left(0.1 \mathrm{~m}^{2}\right)$. Mud samples from the grab were placed on large stainless steel screens $12.0 \mathrm{~mm}$

\footnotetext{
- Mention of product names does not imply endorsement by the United States Environmental Protection Agency (USEPA). Although the research described in this article was funded by the USEPA, it has not been subjected to Agency review and therefore does not necessarily reflect the views of the Agency and no official endorsement should be inferred
}

mesh) and washed with fresh seawater to release organisms from the sediment. Cerianthids were carefully eased out of their tubes (when necessary), and fixed whole in Helly's solution (Barszcz \& Yevich 1975), without prior relaxation, for 5 to $10 \mathrm{~h}$. Specimens were washed in several changes of tap water and stored in $70 \%$ undenatured ethanol. For processing, anemones were sectioned in half longitudinally, dehydrated and cleared with Technicon reagents (S-29 and UC-670), and embedded in Paraplast (Yevich \& Barszcz 1981). Tissues were sectioned at $6 \mathrm{um}$ and stained with Harris' hematoxylin and eosin ( $\mathrm{H} \& \mathrm{E})$. Additional sections of some specimens were stained with Heidenhain's aniline blue method for connective tissue; modified Movat's pentachrome technique for mucous secretory cells, periudic did schiff reaction (FAS) with alcianin blue for carbohydrates; Feulgen reaction with light green counterstain for deoxyribonucleic acid; Heidenhain's iron hematoxylin with PAS counterstain for microparasites (A. Cali pers. comm.); Twort's method for Gram positive and Gram negative bacteria (Rhode Island Hospital); and fixed and stained with chromic acid/osmium tetroxide to demonstrate lipid accumulations (Luna 1968).

Slides were examined and photographed with the light microscope. The condition of tissues was ranked on a scale of 1 to 5 . This system considered the number and type of lesions present, as well as their severity and how they might affect the overall ability of the anemone to function in normal food-gathering, digestion/assimilation (metabolic), reproduction, and protective activities. For example, specimens with no observable lesions in their tissues were rated in excellent condition (a score of 1); those with slight to moderate parasite infections and/or other lesions, such as patches of vacuolated epidermis or minor tissue necrosis, were described in good condition (1.5 to 2); those with extensive parasite infections and/or other lesions were considered to be in fair condition (2.5 to 3); and those specimens with loss of mucous secretory cells and large areas of tissue necrosis were in poor condition ( 3.5 to 4 ). Specimens exhibiting extensive tissue necrosis suggestive of irreversible changes or death were rated 4.5 to 5 on this scale.

Scores obtained for specimens collected on each date were compared, by station, using nonparametric statistical techniques. The Kruskal-Wallis one-way analysis of variance (Steel \& Torrie 1960) was applied to data for each station to compare differences in condition scores between collection dates, both before and after dredge spoil release. Data obtained at each date were also compared between the 4 stations. The Mann-Whitney U-test was used to test for differences between control and exposed stations for each date after May 1983.

Gonads of Ceriantheopsis americanus develop from 
interstitial cells in or near the mesoglea on the longer first and third quartettes of metamesenteries, the second and fourth are shorter and sterile. Gonad development was graded on the appearance of ova and spermaries using five categories: neutral; only ova developing; ova and spermaries present; mature gonads; spawning.

\section{RESULTS}

Summaries of the condition scores of cerianthids from each station are presented in Table 1. Significant histopathological changes encountered in anemones are summarized in Tables 2 to 5 , and shown in Figs. 1 to 12. The total number of anemones examined was 510 .

There was much variability in condition between specimens collected from each station during the study period, with significant differences between dates $(p<$ 0.01 ). Prior to dredge disposal, there were no significant differences between stations for each data except for April 1983, when anemones from the REFS and 1000E stations had extensive microparasite infections. There were significant differences in condition scores between stations for each date during the summer of 1983 following the release of dredged materials at CNTR. In June, anemones from the $200 \mathrm{E}$ station were in significantly poorer condition $(p<0.00)$ than those from the other 3 stations (lesions described below). Statistical analysis of condition scores in July indicated that anemones from the $1000 \mathrm{E}$ station were significantly different only from those at the $200 E$ station, but there were no differences between the other station comparisons. Only 3 anemones from each of 2 stations were obtained in August: the ones from the $1000 \mathrm{E}$ station were in excellent condition, while those from the $400 \mathrm{E}$ station had extensive mesenterial filament necrosis. In September 1983, specimens from the $1000 \mathrm{E}$ station were in good condition, while those from the other 3 stations were in fair to poor condition due to microparasite infections. Later collections showed anemones in generally good condition, with microparasite infections influencing condition scores at $400 \mathrm{E}$ and $200 \mathrm{E}$ in June, and at the REFS and 1000 E stations in October 1984.

Almost all anemones experienced some damage to the epidermis and occasionally to the subepidermal muscles as a result of removal from tubes. This damage manifested itself as physical scraping of the epidermal cell layer (Fig. 1), sometimes with nicks in the muscles, and was quite different from the cellular necrosis seen in other specimens (below). Many specimens had a parasitic infection of the lobes of the mesenterial filaments (Tables 2 to 5, Figs. 2 and 3). The organisms, represented by several stages, were contained in the phagocytic cells of the lobes, causing vacuolation and
Table 1 Ceriantheopsis americanus. Summary of condition scores of anemones collected from each station for each sampling date. Values are: $n=$ number of anemones examined; Mean $(S D)=$ Mean condition score determined for each group with standard deviation in parentheses; range $=$ range of scores found in each group, $-=$ no anemones sampled on that date

\begin{tabular}{|c|c|c|c|c|}
\hline \multirow[t]{2}{*}{ Date } & \multicolumn{4}{|c|}{ Station } \\
\hline & REFS & $1000 \mathrm{E}$ & $400 E$ & $200 \mathrm{E}$ \\
\hline \multicolumn{5}{|c|}{$\begin{array}{l}\text { Prior to dumping } \\
11 \text { Jan } 1982\end{array}$} \\
\hline $\begin{array}{l}\mathrm{n} \\
\text { Mean (SD) } \\
\text { Range }\end{array}$ & $\begin{array}{c}20 \\
2.0(0.8) \\
1-3.5\end{array}$ & - & $\begin{array}{c}3 \\
1.3(0.3) \\
1-1.5\end{array}$ & - \\
\hline $\begin{array}{l}16 \text { Nov } 1982 \\
n \\
\text { Mean (SD) } \\
\text { Range }\end{array}$ & $\begin{array}{c}6 \\
1.7(0.5) \\
1-2.5\end{array}$ & - & - & - \\
\hline $\begin{array}{l}16 \text { Feb } 1983 \\
\text { n } \\
\text { Mean (SD) } \\
\text { Range }\end{array}$ & $\begin{array}{c}19 \\
1.6(0.5) \\
1-2.5\end{array}$ & - & $\begin{array}{c}7 \\
1.7(0.3) \\
1.5-2\end{array}$ & - \\
\hline $\begin{array}{l}12 \text { Apr } 1983 \\
\text { n } \\
\text { Mean (SD) } \\
\text { Range }\end{array}$ & $\begin{array}{c}14 \\
2.2(0.6)^{\mathrm{d}} \\
1.5-3\end{array}$ & $\begin{array}{c}6 \\
2.3(0.3)^{\mathrm{a}} \\
2-2.5\end{array}$ & $\begin{array}{c}6 \\
1.6(0.2) \\
1.5-2\end{array}$ & - \\
\hline $\begin{array}{l}\text { Immediately } \\
6 \text { Jun } 1983 \\
\text { n } \\
\text { Mean (SD) } \\
\text { Range }\end{array}$ & $\begin{array}{l}\text { er dumpins } \\
\begin{array}{c}20 \\
1.8(0.4) \\
1-3\end{array}\end{array}$ & $\begin{array}{c}15 \\
2.0(0.5) \\
1.5-3\end{array}$ & $\begin{array}{c}17 \\
2.2(0.3) \\
1.5-2.5\end{array}$ & $\begin{array}{c}7 \\
3.5(0.6) \\
3-4.5\end{array}$ \\
\hline $\begin{array}{l}14 \text { Jul } 1983 \\
\text { n } \\
\text { Mean (SD) } \\
\text { Range }\end{array}$ & $\begin{array}{c}16 \\
1.7(0.8) \\
1-4.5\end{array}$ & $\begin{array}{c}16 \\
1.4(0.3) \\
1-2\end{array}$ & $\begin{array}{c}18 \\
1.9(0.5) \\
1.5-3\end{array}$ & $\begin{array}{c}18 \\
2.6(1.0) \\
1.5-4.5\end{array}$ \\
\hline $\begin{array}{l}2 \text { Aug } 1983 \\
\text { n } \\
\text { Mean (SD) } \\
\text { Range }\end{array}$ & - & $\begin{array}{c}3 \\
1.0(0.0) \\
1\end{array}$ & $\begin{array}{c}3 \\
2.8(0.3) \\
2.5-3\end{array}$ & - \\
\hline $\begin{array}{l}8 \text { Sep } 1983 \\
\text { n } \\
\text { Mean (SD) } \\
\text { Range }\end{array}$ & $\begin{array}{c}\stackrel{7}{7}^{\mathrm{a}} .1(1.1)^{\mathrm{a}} \\
1.5-4\end{array}$ & $\begin{array}{c}10 \\
1.7(0.4) \\
1-2.5\end{array}$ & $\begin{array}{c}10 \\
2.5(0.3)^{a} \\
2-3\end{array}$ & $\begin{array}{c}7 \\
2.9(0.7)^{\mathrm{a}} \\
2-3.5\end{array}$ \\
\hline $\begin{array}{l}\text { During later } \\
\text { 14 Dec } 1983\end{array}$ & nitoring & & & \\
\hline $\begin{array}{l}\mathrm{n} \\
\text { Mean (SD) } \\
\text { Range }\end{array}$ & $\begin{array}{c}21 \\
1.4(0.3) \\
1-2\end{array}$ & $\begin{array}{c}27 \\
1.7(0.3) \\
1-2\end{array}$ & $\begin{array}{c}30 \\
1.7(0.4) \\
1 .-2.5\end{array}$ & - \\
\hline $\begin{array}{l}15 \text { Mar } 1984 \\
\mathrm{n} \\
\text { Mean (SD) } \\
\text { Range }\end{array}$ & $\begin{array}{c}25 \\
1.7(0.6) \\
1-3\end{array}$ & $\begin{array}{c}18 \\
2.0(0.3) \\
1.5-2.5\end{array}$ & $\begin{array}{c}10 \\
1.9(0.5) \\
1.5-3\end{array}$ & $\begin{array}{c}3 \\
1.3(0.3) \\
1-1.5\end{array}$ \\
\hline $\begin{array}{l}21 \text { Jun } 1984 \\
\text { n } \\
\text { Mean (SD) } \\
\text { Range }\end{array}$ & $\begin{array}{c}25 \\
2.0(0.3) \\
1.5-3\end{array}$ & $\begin{array}{c}21 \\
2.1(0.3) \\
1.5-3\end{array}$ & $\begin{array}{c}20 \\
2.3(0.7)^{a} \\
1.5-4\end{array}$ & $\begin{array}{c}4 \\
2.5(1.0)^{\mathrm{a}} \\
2-4\end{array}$ \\
\hline $\begin{array}{l}10 \text { Oct } 1984 \\
\text { n } \\
\text { Mean (SD) } \\
\text { Range }\end{array}$ & $\begin{array}{c}16 \\
2.2(0.6)^{a} \\
1-3.5\end{array}$ & $\begin{array}{c}13 \\
2.5(0.5)^{a} \\
1.5-3\end{array}$ & $\begin{array}{c}24 \\
1.8(0.4) \\
1-2.5\end{array}$ & $\begin{array}{c}5 \\
1.7(0.4) \\
1-2\end{array}$ \\
\hline
\end{tabular}


Table 2. Ceriantheopsis americanus. Summary of histopathological changes in individuals from REFS station, expressed as percent anemones exhibiting each condition. TBPRT black particulate in tentacles; TMDEG: tentacle muscle degeneration; TCYST: debris-filled cysts in tentacles; TNECR: tentacle necrosis; TBASB: basophilic bodies in tentacles; MFHYP: hyperplasia of lobes of mesenterial filaments; MFSPR: slight microparasite infection in mesenterial filaments; MFXPR: extensive microparasite infection in mesenterial filaments; MFNEC: necrosis of mesenterial filaments; GDNEC: necrosis of gastrodermis; EPNEC necrosis of epidermis; -: no anemones sampled on that date

\begin{tabular}{|c|c|c|c|c|c|c|c|c|c|c|c|}
\hline Date & TBPRT & TMDEG & TCYST & TNECR & TBASB & MFHYP & MFSPR & MFXPR & MFNEC & GDNEC & EPNEC \\
\hline $11 \operatorname{Jan} 1982$ & 0 & 15 & 0 & 5 & 0 & 0 & 65 & 5 & 10 & 25 & 10 \\
\hline 16 Nov 1982 & 0 & 0 & 0 & 17 & 0 & 0 & 50 & 0 & 17 & 17 & 17 \\
\hline 16 Feb 1983 & 0 & 11 & 0 & 16 & 5 & 0 & 37 & 5 & 26 & 0 & 0 \\
\hline 12 Apr 1983 & 0 & 0 & 0 & 0 & 0 & 7 & 7 & 43 & 43 & 0 & 0 \\
\hline 6 Jun 1983 & 0 & 0 & 0 & 0 & 5 & 0 & 40 & 30 & 45 & 0 & 0 \\
\hline $14 \mathrm{Jul} 1983$ & 0 & 6 & 0 & 6 & 0 & 0 & 0 & 0 & 6 & 6 & 6 \\
\hline 2 Aug 1983 & - & - & - & - & - & - & - & - & - & - & - \\
\hline 8 Sep 1983 & 0 & 0 & 0 & 43 & 0 & 0 & 14 & 29 & 43 & 57 & 0 \\
\hline 14 Dec 1983 & 10 & 0 & 0 & $n$ & 0 & 0 & 10 & 0 & 5 & $n$ & $n$ \\
\hline 15 Mar 1984 & 72 & 0 & 0 & 0 & 0 & 0 & 8 & 4 & 32 & 0 & 0 \\
\hline 21 Jun 1984 & 60 & 0 & 0 & 0 & 0 & 0 & 56 & 16 & 20 & 0 & 0 \\
\hline 10 Oct 1984 & 56 & 0 & 0 & 19 & 0 & 0 & 19 & 69 & 25 & 6 & 0 \\
\hline
\end{tabular}

Table 3. Ceriantheopsis americanus. Summary of histopathological changes in individuals from 1000E station, expressed as percent anemones exhibiting each condition. Abbreviations as in Table 2

\begin{tabular}{|c|c|c|c|c|c|c|c|c|c|c|c|}
\hline Date & TBPRT & TMDEG & TCYST & TNECR & TBASB & MFHYP & MFSPR & MFXPR & MFNEC & GDNEC & EPNEC \\
\hline 11 Jan 1982 & - & - & - & - & - & - & - & - & - & - & - \\
\hline 16 Nov 1982 & - & -- & - & - & - & - & - & - & - & - & - \\
\hline 16 Feb 1983 & - & - & - & - & - & - & - & - & - & - & - \\
\hline 12 Apr 1983 & 0 & 0 & 0 & 0 & 0 & 0 & 0 & 100 & 0 & 0 & 0 \\
\hline 6 Jun 1983 & 0 & 0 & 7 & 7 & 0 & 0 & 60 & 7 & 20 & 7 & 0 \\
\hline $14 \mathrm{Jul} 1983$ & 0 & 0 & 0 & 0 & 0 & 0 & 19 & 0 & 13 & 0 & 0 \\
\hline 2 Aug 1983 & 100 & 0 & 0 & 0 & 0 & 0 & 0 & 0 & 0 & 0 & 0 \\
\hline 8 Sep 1983 & 0 & 0 & 0 & 0 & 0 & 0 & 67 & 0 & 22 & 0 & 0 \\
\hline 14 Dec 1983 & 56 & 0 & 0 & 0 & 4 & 0 & 26 & 0 & 7 & 0 & 0 \\
\hline 15 Mar 1984 & 61 & 0 & 0 & 0 & 0 & 0 & 11 & 0 & 39 & 0 & 17 \\
\hline 21 Jun 1984 & 90 & 0 & 0 & 0 & 0 & 0 & 24 & 0 & 71 & 5 & 0 \\
\hline 10 Oct 1984 & 53 & 0 & 0 & 8 & 0 & 0 & 38 & 46 & 38 & 0 & 0 \\
\hline
\end{tabular}

Table 4. Ceriantheopsis americanus. Summary of histopathological changes in individuals from $400 \mathrm{E}$ station, expressed as percent anemones exhibiting each condition. Abbreviations as in Table 2

\begin{tabular}{|c|c|c|c|c|c|c|c|c|c|c|c|}
\hline Date & TBPRT & TMDEG & TCYST & TNECR & TBASB & MFHYP & MFSPR & MFXPR & MFNEC & GDNEC & EPNEC \\
\hline $11 \operatorname{Jan} 1982$ & 0 & 0 & 0 & 0 & 0 & 0 & 0 & 0 & 0 & 0 & 0 \\
\hline 16 Nov 1982 & - & - & - & - & - & - & - & - & - & - & - \\
\hline 16 Feb 1983 & 0 & 0 & 0 & 0 & 14 & 14 & 14 & 14 & 14 & 0 & 0 \\
\hline 12 Apr 1983 & 0 & 0 & 0 & 0 & 0 & 0 & 33 & 17 & 0 & 0 & 0 \\
\hline 6 Jun 1983 & 0 & 0 & 0 & 6 & 0 & 0 & 29 & 0 & 59 & 6 & 0 \\
\hline 14 Jul 1983 & 0 & 0 & 0 & 0 & 17 & 6 & 0 & 6 & 17 & 0 & 0 \\
\hline 2 Aug 1983 & 67 & 0 & 0 & 0 & 0 & 0 & 0 & 0 & 100 & 67 & 0 \\
\hline 8 Sep 1983 & 10 & 0 & 0 & 0 & 0 & 0 & 50 & 30 & 20 & 20 & 10 \\
\hline 14 Dec 1983 & 87 & 37 & 0 & 0 & 13 & 7 & 10 & 7 & 23 & 0 & 0 \\
\hline $15 \mathrm{Mar} 1984$ & 70 & 20 & 10 & 0 & 0 & 0 & 20 & 20 & 70 & 0 & 0 \\
\hline 21 Jun 1984 & 75 & 0 & 0 & 25 & 0 & 0 & 40 & 20 & 45 & 10 & 15 \\
\hline 10 Oct 1984 & 79 & 0 & 0 & 0 & 4 & 0 & 42 & 46 & 33 & 0 & 0 \\
\hline
\end{tabular}


Table 5. Ceriantheopsis americanus. Summary of histopathological changes in individuals from 200E station, expressed as percent anemones exhibiting each condition. Abbreviations as in Table 2

\begin{tabular}{|c|c|c|c|c|c|c|c|c|c|c|c|}
\hline Date & TBPRT & TMDEG & TCYST & TNECR & TBASB & MFHYP & MFSPR & MFXPR & MFNEC & GDNEC & EPNEC \\
\hline 11 Jan 1982 & - & - & - & - & - & - & - & - & - & - & - \\
\hline 16 Nov 1982 & - & - & - & - & - & - & - & - & - & - & - \\
\hline 16 Feb 1983 & - & - & - & - & - & - & - & - & - & - & - \\
\hline 12 Apr 1983 & - & - & - & - & - & - & - & - & - & - & - \\
\hline 6 Jun 1983 & 43 & 0 & 0 & 57 & 0 & 0 & 0 & 0 & 86 & 57 & 100 \\
\hline $14 \mathrm{Jul} 1983$ & 0 & 17 & 0 & 28 & 0 & 6 & 0 & 0 & 22 & 44 & 67 \\
\hline 2 Aug 1983 & - & - & - & - & - & - & - & - & - & - & - \\
\hline 8 Sep 1983 & 0 & 0 & 0 & 29 & 0 & 0 & 43 & 43 & 71 & 71 & 85 \\
\hline 14 Dec 1983 & - & - & - & - & - & - & - & - & - & - & - \\
\hline 15 Mar 1984 & 67 & 0 & 0 & 0 & 0 & 0 & 0 & 0 & 0 & 0 & 67 \\
\hline 21 Jun 1984 & 50 & 0 & 0 & 25 & 0 & 25 & 50 & 0 & 25 & 25 & 50 \\
\hline 10 Oct 1984 & 0 & 0 & 0 & 0 & 20 & 20 & 40 & 20 & 0 & 0 & 20 \\
\hline
\end{tabular}

eventually necrosis of the cells. Microparasites were observed throughout the study, but infections were lowest in winter. An interesting condition consisting of hypertrophy and hyperplasia of filament lobes, with extended eosinophilic columnar gastrodermal cells (Fig. 4), was observed in several anemones from the REFS, 400E and 200E stations, but did not appear to be related to parasite infection or spoil disposal. One specimen from the $1000 \mathrm{E}$ station and 1 from the $400 \mathrm{E}$ station possessed rounded cyst-like structures on the tentacles containing necrotic gastrodermal debris extending through the mesoglea and thinning the epidermis surrounding the mass (Fig. 5). Several specimens from all 4 stations on various dates contained 1 to a few ovoid basophilic finely granular bodies surrounded by cells or within the mesoglea of the tentacles or upper mesenteries (Fig. 6). In the June 1983 collection at 200E, 3 of 9 anemones contained patches of refractile, brown to black fine granules in the phagocytic gastrodermal cells of tentacles and upper mesenteries (Fig. 7). More anemones with this condition were found in the following months from all stations (up to $100 \%$ in August 1983 at 1000E).

Six anemones from the REFS station collected prior to August 1983 showed degeneration of muscles in the tentacles, appearing as separation and rounding of fibers with loss of normal architecture (Fig. 8). This condition was also found in several individuals from the $400 \mathrm{E}$ and $200 \mathrm{E}$ stations on 3 dates. There was slight necrosis in tentacles of a few anemones from different collections at all stations, although about $40 \%$ of specimens from the September 1983 REFS collection exhibited minor tentacle and mesenterial filament necrosis, with microparasites present in the mesenterial filaments. Over half the specimens obtained at that time also showed necrosis of the gastrodermis. One specimen, collected from the REFS station on 14 July 1983 , exhibited extensive areas of muscle degeneration and cellular necrosis. A number of anemones exhibited a condition in which gastrodermal cells, including those of the mesenterial filaments and mesenteries, accumulated slight to large quantities of cellular debris, including pycnotic nuclei, refractile granules, and normalappearing spirocysts (Mariscal et al. 1976) in chaotic patterns (Fig. 9). This condition was evident in anemones with severe parasite infections although sometimes no evidence of parasites was present. This cellular debris did not appear to be correlated with feeding activities, because many anemones contained minute crustacean prey and other materials in the gastric cavity. A few anemones from all stations showed patches of epidermis where basal ptychocysts and mucous secretory cells were missing or necrotic compared to normal epidermis (Fig. 10).

Following dumping of the dredge spoil in May 1983, all anemones collected from the 200E station showed extensive areas of degeneration of the epidermis in various stages, with loss of ptychocysts and mucous cells, vacuolation and necrosis (Fig. 11). These individuals also exhibited necrosis of tentacles, mesenterial filaments, and the gastrodermal regions (Fig. 12). The number of anemones available for histopathological examinations were noticeably fewer at the $200 \mathrm{E}$ station than at the other stations at this time. Most Ceriantheopsis americanus remained in poor condition at this station in July, when epidermal necrosis was also found in $67 \%$ of anemones. By September, $85 \%$ of anemones from this station exhibited epidermal necrosis, but one-half of those cases resembled the patchy necrosis seen occasionally at the other stations. In June 1984 there was 1 case with extensive necrosis and 1 with patchy necrosis (out of 4 anemones). Microparasites were not present in the mesenterial filaments of anemones collected in June and July 1983 from the 

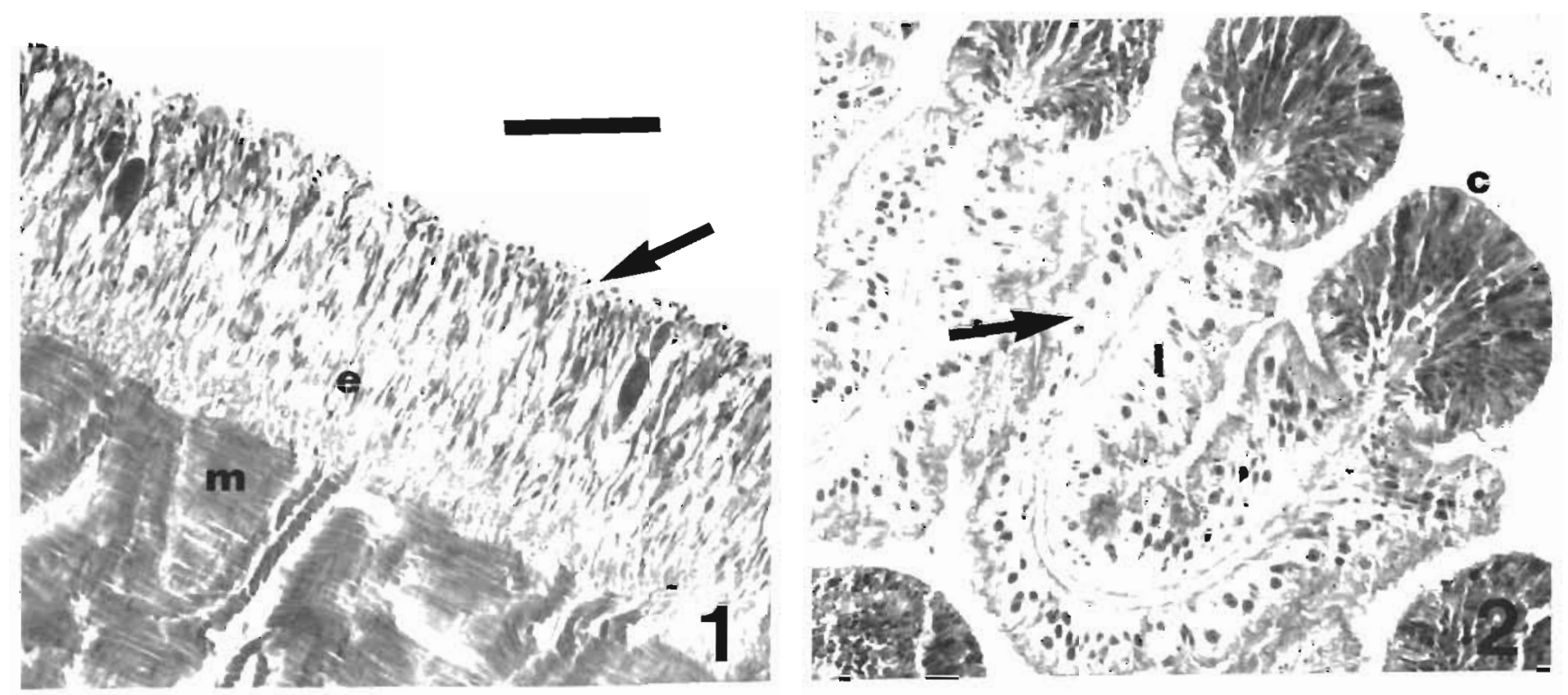

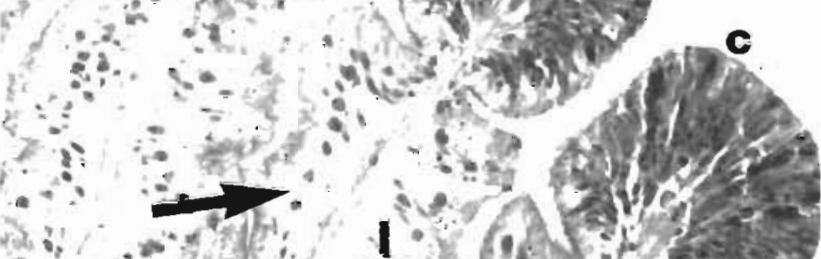

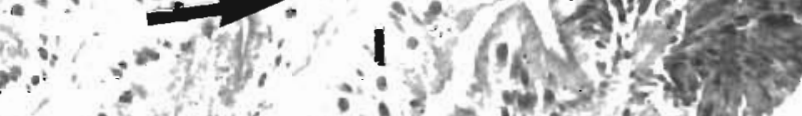

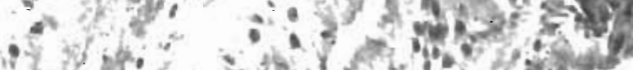

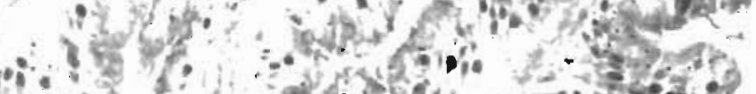

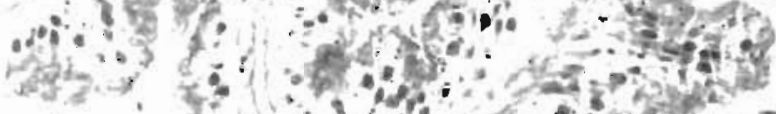

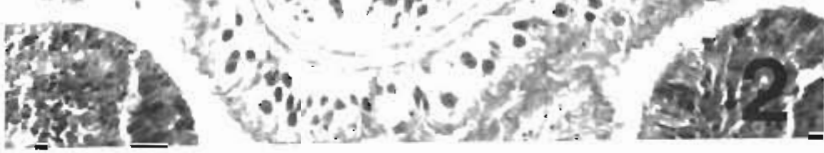

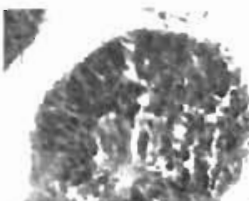

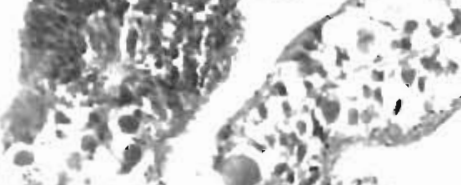

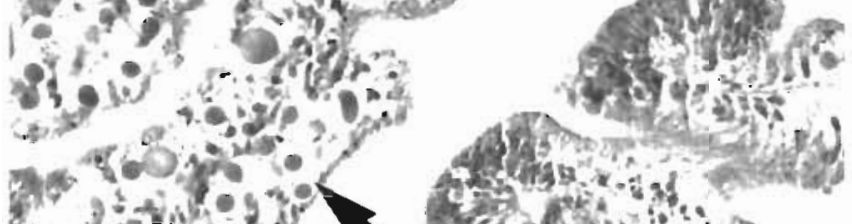

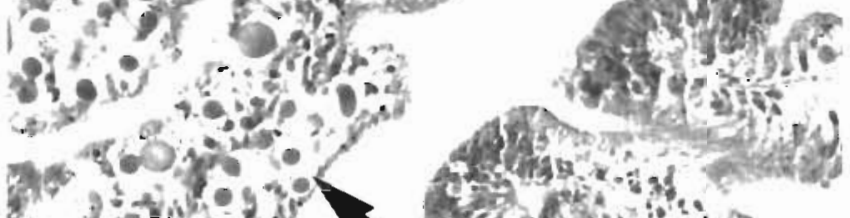

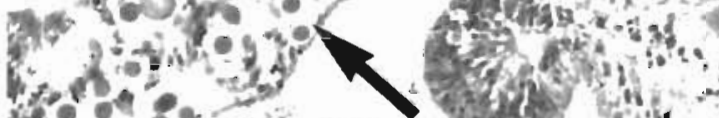

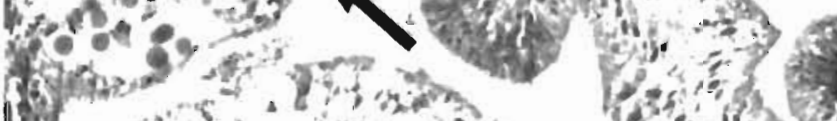

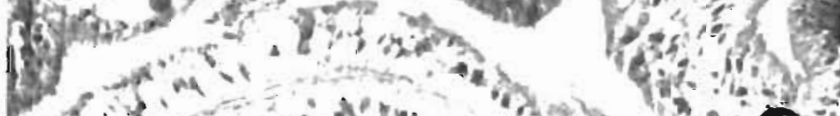

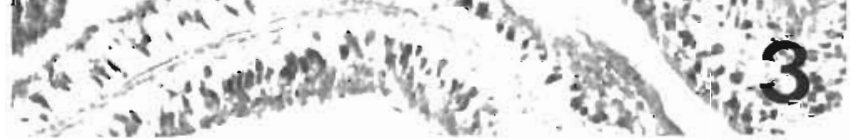

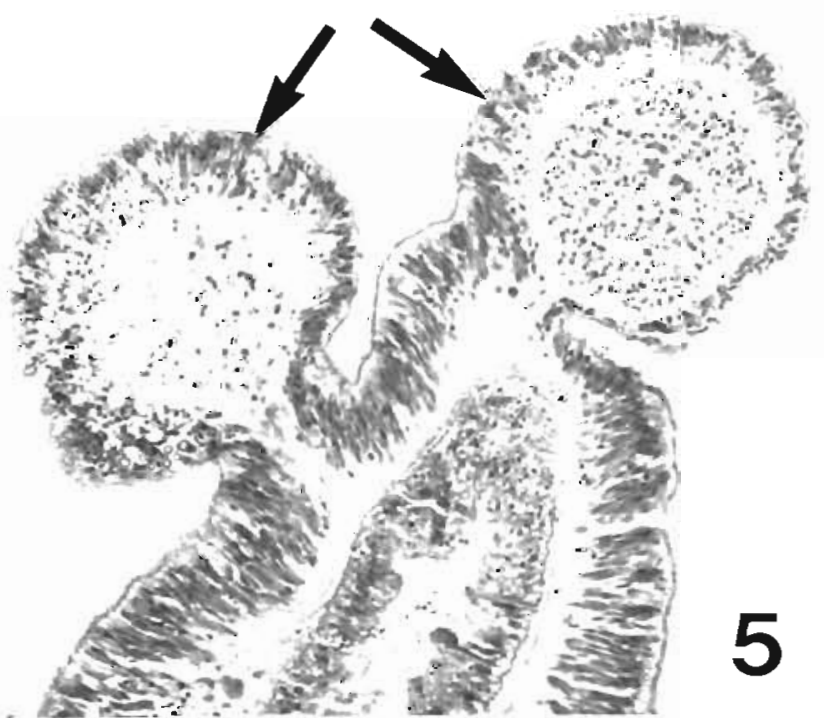

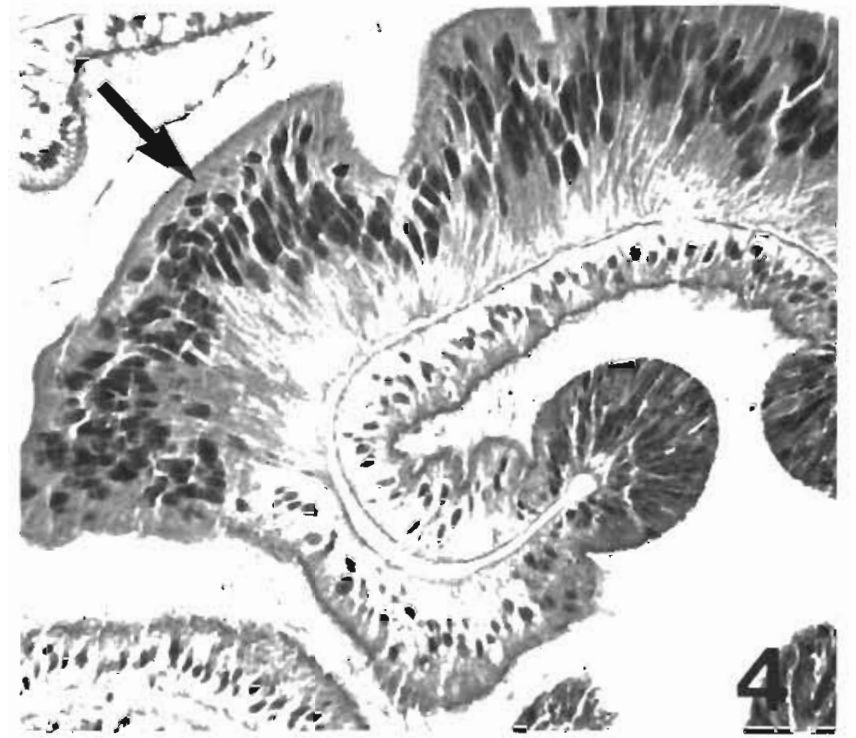

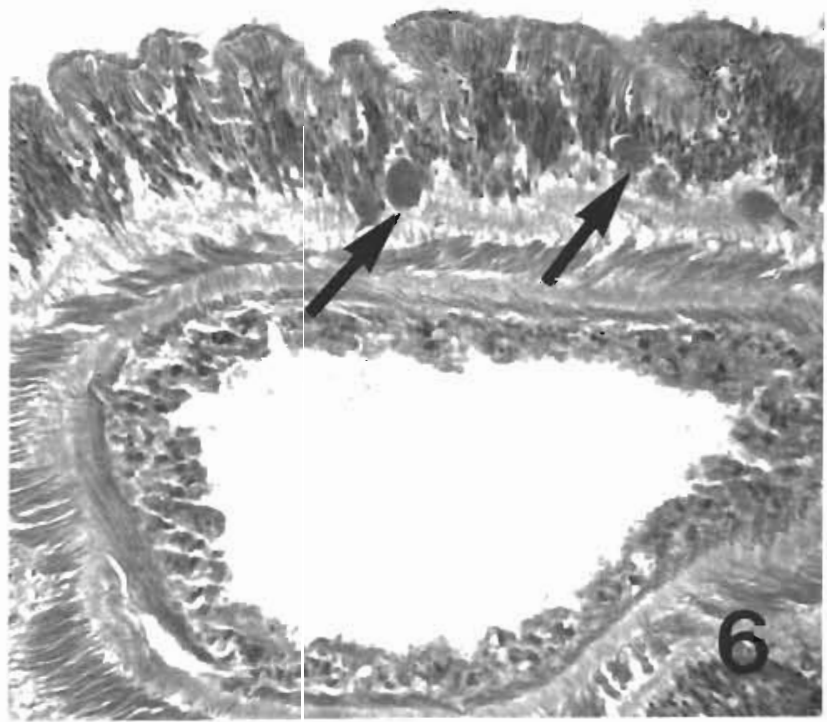


200 E station, although they occurred in anemones at other stations. They were found in $43 \%$ of anemones at this station in September 1983, as well as at most of the other stations in this and later collections.

Fertile mesenteries of Ceriantheopsis americanus were composed of large gastrodermal cells, with apical nuclei, which appeared clear in $\mathrm{H}$ \& E preparations. These cells stained with osmium tetroxide, indicating lipid storage areas. Only smaller anemones (under $2 \mathrm{~cm}$ contracted length) were found to be neutral, presumably sexually immature. Some anemones contained only developing oocytes, but as vitellogenesis proceeded, spermaries appeared. At maturity, spawning occurred by rupturing through the mesentery, with phagocytic cells of the mesenteries participating in cleaning up remnants of spermatozoa, which were often visible as primary oocytes were also developing. Spawning occurred first in the oral regions of anemones, proceeding aborally, with new ova development following this pattern.

The percentage of anemones from each station that exhibited each stage of gonad development varied widely between sites at each date. Generally, some portion of each group could be found at each stage of development throughout the year (Fig. 13). These data indicate spawning peaks in early spring and early fall. The presence of mature and spawning individuals at each station varied with each date. Neutral anemones were found at all seasons. Resorption of mature ova was observed in a few specimens, but was not correlated with exposure to the dredge spoil. However, most cases of ova resorption occurred in September and October in post-spawning anemones with extensive parasite infections. Abnormal gonad development and necrosis of ova and spermaries were found in specimens collected from the 200E station in June 1983 (immediately after dredge disposal), and premature ova extrusion occurred in 3 specimens in fair to poor condition obtained from this station in July 1983

\section{DISCUSSION}

During the FVP study of the effects of Black Rock Harbor (BRH) dredge spoil discharge at the CLIS site, several laboratory investigations were undertaken to examine effects of the sediment on invertebrate physiology, biochemistry, behavior and histopathology.
Many of the organic contaminants found in the BRH dredged materials were accumulated by mussels (Mytilus edulis) and polychaete worms (Nereis virens) by up to 3 orders of magnitude in $28 \mathrm{~d}$ laboratory exposures. Inorganic compounds were taken up much less readily. Although depuration rates of the organic compounds generally reflected $n$-octanol/water partition coefficients, there was some long-term storage of hydrocarbons in tissues of these organisms even after $5 \mathrm{wk}$ depuration (Lake et al. 1985). Histopathological examinations during that experiment revealed various degenerative changes in the tissues of filter feeding mussels ( $M$. edulis), tube-building amphipods (Ampelisca abdita), and annelid worms (Nepthys incisa, Neanthes arenaceodentata). No histological changes were found in the deposit feeding bivalve Yoldia limatula, perhaps because it did not actively feed and process sediment (as confirmed by feeding studies, Rogerson et al. 1985) and thus did not receive the expected exposure (Yevich et al. 1986). There was significant degeneration of mucous secreting cells in both $A$. abdita and $N$. arenacoedentata; the mucus is utilized in burrow construction in these organisms.

Another study examined the correlation of field and laboratory exposures of mussels and Nepthys incisa with histopathological effects and tissue residues (Yevich et al. 1987). In this case, tissue residues of organics and water chemistry conditions at the field stations (1000E, 400E, REFS) indicated that mussels, placed in baskets $1 \mathrm{~m}$ above the bottom, received only brief exposures to BRH sediments (for up to 2 mo at $400 \mathrm{E}$ ), and that worms were subjected to sediment levels which they had demonstrated could be tolerated in the laboratory. No adverse histological changes were found during this field exposure. Gardner \& Yevich (1988) reported histopathological examinations performed on a variety of other species that were also exposed to resuspended BRH sediment, Lesions found in invertebrates exposed to sediment and not in invertebrate controls included gill water tube tumors in oysters placed at the $400 \mathrm{E}$ station for $36 \mathrm{~d}$ following dredge disposal and in BRH for $30 \mathrm{~d}$. In laboratory exposures, oysters developed neoplasms of the kidney, gastrointestinal tract, gonad, gill, heart and neural elements; there was necrosis of digestive tubules and ducts and heart myxoma in mussels; softshells exhibited necrosis of kidney, red gland, digestive tubules and ganglia, and inflammation in the gills and siphons;

Figs. 1 to 12. Ceriantheopsis americanus. Scaie bar for all figures (in Fig. 1) $=100 \mu \mathrm{m}$

Fig. 1. Scraped epidermis (e), note loss of cells from distal region cf. Fig. 10, normal epidermis); m: underlying muscles. Fig. 2. Normal mesenterial filaments. l: lobes (at arrow); c: cnidoglandular cap. Fig. 3. Various stages of unidentified microparasite in mesenterial filament lobes. Note vacuolation of cells (arrow). Fig. 4. Hypertrophy and hyperplasia of lobes of mesenterial filaments (at arrow). Fig. 5. Two tentacular cysts (arrows), filled with cellular debris. Fig. 6. Ovoid basophilic bodies in epidermis of tentacle (at arrows). (Continued overleaf) 

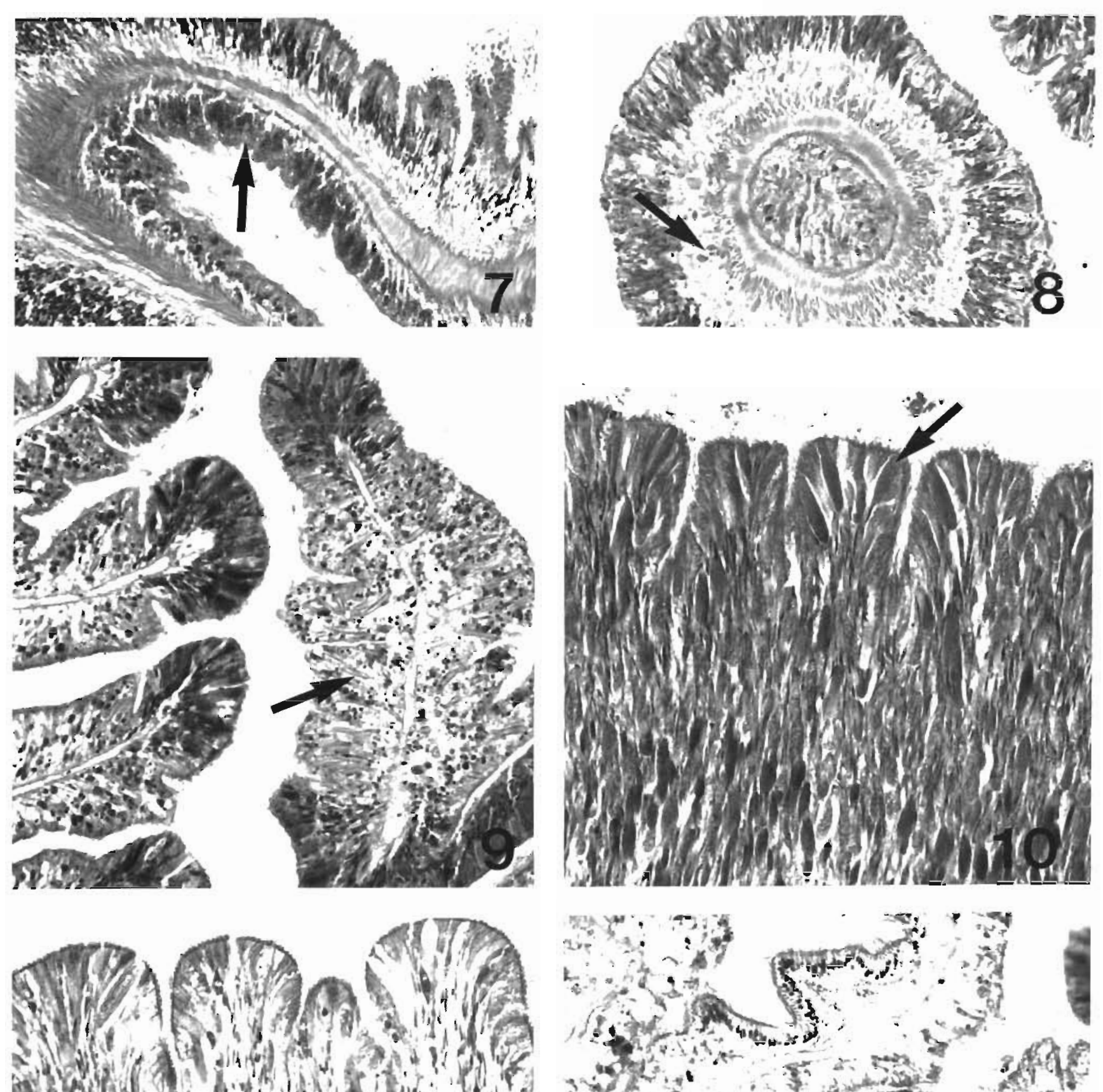

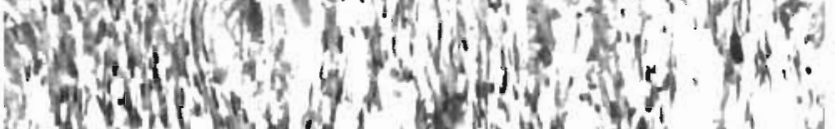

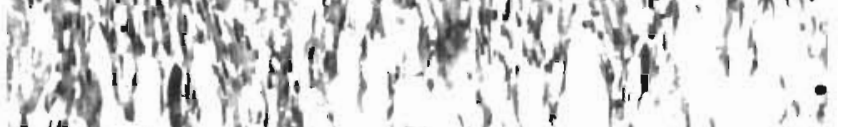
(N)

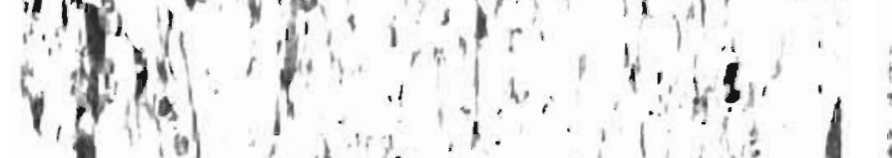

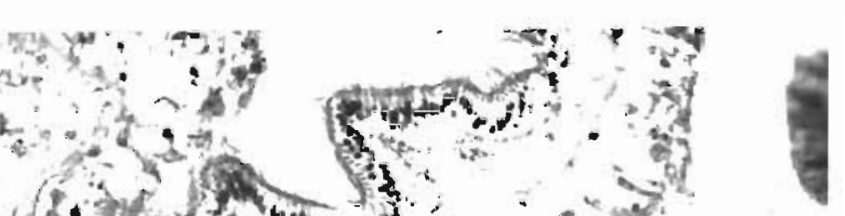

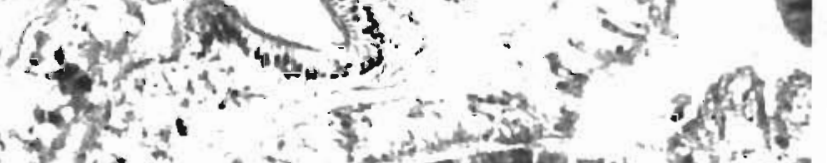
3.

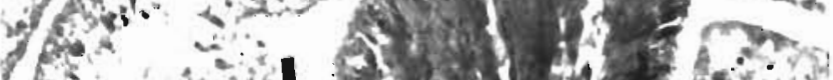

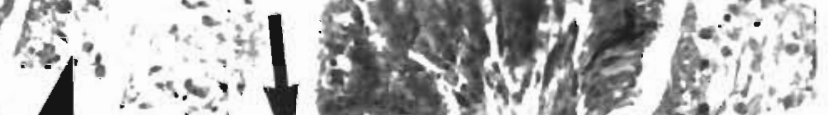

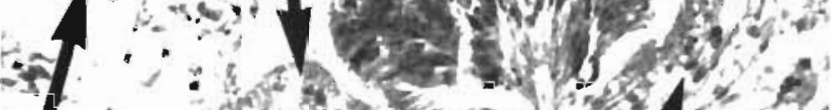

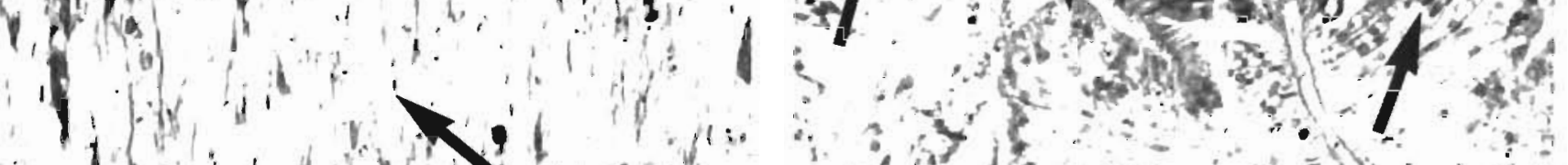
(o) 

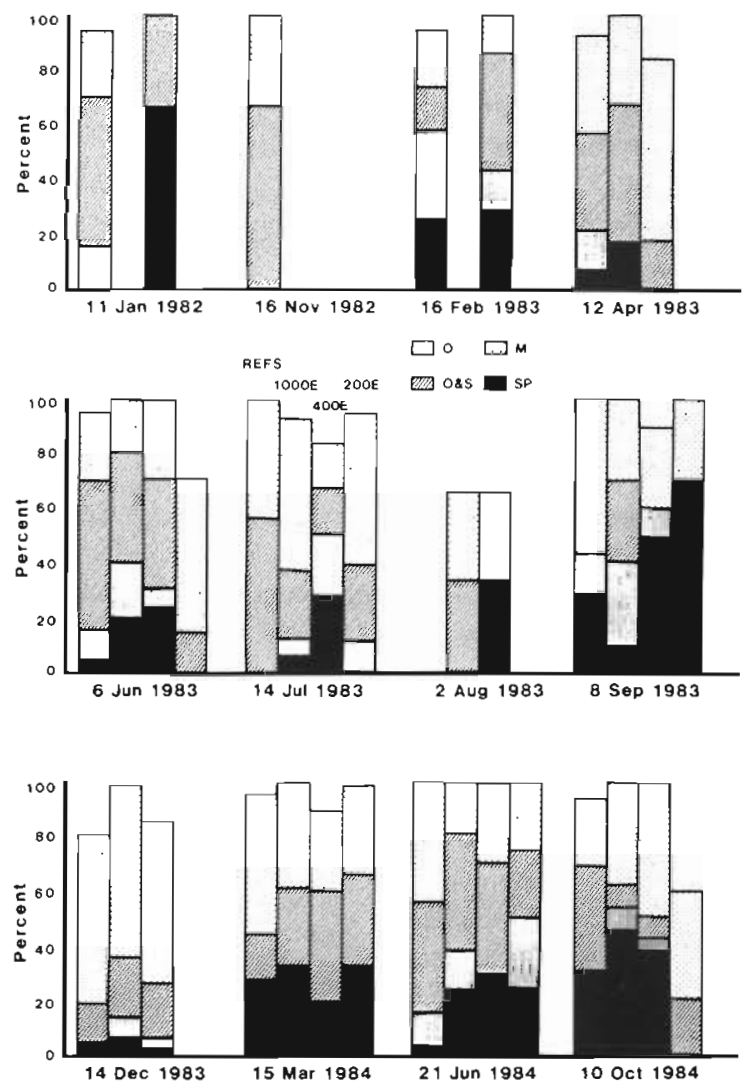

Fig. 13. Ceriantheopsis americanus. Gonad deveopment for individuals from FVP stations, expressed as percentage in each stage of the reproductive cycle for 8 dates. O: only ova developing; $\mathrm{O} \& \mathrm{~S}$; ova and spermaries present; $\mathrm{M}$ : mature gonads; SP: spawning. Each set of bars represents (left to right) the data from the REFS, 1000E, 400E, and 200E stations

scallops had necrosis of digestive tubules and inflammation of kidney connective tissue folds; and a temperate coral developed hyperplasia of mucous secretory cells. No significant changes were found in lobsters during laboratory exposures (Gardner \& Yevich 1988).

Except for the present study, there were no histopathological examinations performed on other benthic organisms collected from the field before and after dumping of dredge spoil. Scott et al. (1987) reported on benthic recolonization at the FVP site. They noted that the immediate impact was the burial of the benthic community within the $200 \mathrm{~m}$ contour of CNTR, although most of the bivalve and polychaete infaunal community at 200 E probably escaped burial by upward migration.
The bivalves Mulinia laterali, Yoldia limatula and Nucula annulata were still abundant at this station immediately after disposal operations ceased, but their populations may have experienced subsequent mortalities within 2 to 6 mo. The $200 \mathrm{E}$ station received more toxic, silty, sediments than the central dumpsite. By December of 1983, species numbers at 200E had returned to background levels, and species numbers at all stations were similar by mid-1984, with a more diverse assemblage at CNTR. Ceriantheopsis americanus was not considered to be a significant member of the infaunal community. The number of anemones collected per grab sample was highly variable, however, the mean number of anemones collected per 5 grabs at each station was less at the CNTR and 200E stations prior to the dredge spoil disposal (collections made in December 1982 and March 1983). After sediment disposal in May 1983, no anemones were collected from the CNTR station until June 1985, and there were fewer per sample than at the REFS station. From June to December 1983, the mean number of $C$. americanus varied at the other stations, but fewer were consistently found at the $200 \mathrm{E}$ station (less than 3 collection $^{-1}$ ), with low numbers from the July $400 \mathrm{E}$ station and September 1000 E and 400 E stations (S. Pratt pers. comm.)

The observations that fewer Ceriantheopsis americanus were found at the CNTR and 200E stations throughout the study, coupled with the lack of collections of anemones for histopathological examination from the $200 \mathrm{E}$ station prior to the dumping of $\mathrm{BRH}$ dredged material, prevent a clear correlation of spoil exposure to observed lesions in the present study. Anemones from the 200E station collected 1 mo after disposal exhibited extensive tissue necrosis, especially in the loss of mucous secretory cells and ptychocysts from the epidermis. The frequency and intensity of this lesion decreased in anemones from this station in the following months. This lesion was not found in anemones from any other station at that time, or during other collections. The data suggest that $C$. americanus may be adversely affected by acute exposures to high levels of hydrocarbons and heavy metals, as seen during laboratory exposures of other invertebrates (e.g. Yevich et al. 1986, Gardner \& Yevich 1988), but the effects may also be related to the high turbidity and sedimentation rates during the release of $B R H$ sediments.

Many cnidarians and ctenophores are known to be sensitive to compounds similar to the BRH spoil compo-

Figs. 1 to 12 (continued). Fig. 7. Fine granular dark refractile particulate matter in gastrodermis of tentacle (at arrow). Fig. 8 . Degeneration of muscles (arrow) in cross-section of tentacle. Fig. 9. Necrosis of mesenterial filament. Note that lobes are filled with cellular debris and spirocysts (at arrow). Fig. 10. Normal epidermis. Note numerous ptychocysts (at arrow), and flagellated border Fig. 11. Epidermis of anemone from 200E station collected on 6 June 1983. Note vacuolation (at arrow), with loss of ptychocysts and mucous secretory cells. Fig. 12. Necrosis of mesenteries and mesenterial filaments in anemone from $200 \mathrm{E}$ station after dredge spoil disposal. Note accumulations of cell debris in gastrodermal cells (arrows) 
nents (Evans 1977, Stebbing 1979, Loya \& Rinkevich 1980, MacLean et al. 1981, Szmant-Froelich et al. 1981). The lipid-rich tissues of these organisms have a particularly high affinity for hydrocarbons, which they may retain for long periods (Peters et al. 1981, Knap et al. 1983, Solbakken 1985). Although some samples of Ceriantheopsis americanus were collected for chemical evaluation, the tissue analyses were never performed so we cannot state that hydrocarbon uptake was a factor in this study. Pearce (1972) and Carioccolo \& Steimle (1983) proposed that the tube offered protection for cerianthid anemones in stressed environments. Sassaman \& Mangum (1974) examined the diffusion of oxygen in $C$. americanus and noted that gas exchange occurred primarily across the tentacle crown, and irrigation of tubes was uniikely. Alier (1983) studied the diffusive permeability of burrow linings of $C$. americanus. He noted that the thick tube $(620 \mu \mathrm{m})$ was lined with polysaccharides and proteins, and exhibited a high diffusive permeability. This permeability was dependent on the $\mathrm{pH}$ and charge of the lining. Because of a net negative charge, positively-charged ions would move through the lining more readily, thus hydrogen sulfide would be restricted to the external side of the burrow. He further proposed that the linings would hinder diffusion of larger dissolved organic molecules. It may be more likely that anemones would acquire toxic metals and compounds from feeding on prey organisms. C. americanus is thought to be a suspension feeder, eating particulates and small planktonic organisms, and utilizing extracellular and extracorporeal contact digestion from enzymes produced in the epidermis of labial tentacles (Tiffon 1975). The toxicity of the dredge spoil and/or high turbidity levels associated with the waste disposal probably affected the diversity and abundance of possible prey items in the area (Pearson \& Rosenberg 1978, Scott et al. 1987), so that alterations in diet or lack of food at the $200 \mathrm{E}$ station could also have contributed to the pathology observed in anemones following the discharge, in particular, epidermal lesions.

The loss of mucous secretory cells and ptychocysts from the epidermis of Ceriantheopsis americanus at the 200E station suggest that energy reserves for cell replenishment were adversely affected, leading to problems with tube formation and the inability of cerianthids to remove sediments from their surfaces. Mucus production in benthic cnidarians is necessary to prevent burial by sedimentation and to protect against toxins or invading microorganisms. Increases in the number and activity of mucous secretory cells have been linked to high levels of turbidity and sedimentation, but the number of functioning mucous secretory cells also decreases with increasing sediment loads. Schumacher (1979) noted the loss of mucous secretory cells that were not replaced in corals exposed to heavy sedimentation. Because production of mucus to prevent burial by sedimentation requires significant energy expenditures, the ability to continue secreting mucus is highly dependent on nutritional status (Peters \& Pilson 1985). Other reports indicate that toxic compounds may directly damage mucous cell metabolism. Peters et al. (1981) noted an initial increase and then atrophy of mucous secretory cells and atrophy of muscle bundles in oil-exposed corals that were correlated with tissue residues following exposure to no. 2 fuel oil hydrocarbons. After $11 \mathrm{~d}$ of constant exposure to resuspended BRH sediments, a temperate coral exhibited hyperplasia of mucous secretory cells compared to coral exposed to resuspended clean sediments (Gardner \& Yevich 1988), but no further observations were made. Mucous secretory cells of amphipods and worms degenerated during laboratory exposures to BRH sediments but not in those exposed to clean sediments (Yevich et al. 1986).

The presence of the unusual microparasites also confuses the message in this study. The damage they produced in the nutritive/absorptive region of the mesenterial filaments also could have adversely affected the anemone's ability to obtain nourishment. The lack of parasites in anemones at the $200 E$ station in June 1983 may indicate that those anemones with parasites had already died within the month following the discharge, either because they were more susceptible to increased sedimentation and chemical stress or because the intensity of the parasite infections had increased when the anemones' normal mechanisms of resistance were weakened. Other studies have suggested that parasite-compromised hosts are more vulnerable to pollutants (Sindermann 1983, Yevich \& Barszcz 1983), although Couch \& Courtney (1977) and Winstead \& Couch (1988) reported enhanced viral and protozoan infections in shrimp and oysters, respectively, when exposed to certain toxic chemicals. In the latter situations, the cause of death could not be attributed to chemical exposure alone. Toxic substances may inhibit the growth and development of parasites, and the frequency of infection, as Farley (1977) noted in a study in which the Dermocystidium marinum (= Perkinsus marinus) pathogen found in Macoma balthica was reduced in clams exposed to higher concentrations of the pesticide dieldrin. However, the fact that there was a patchy distribution of microparasites in Ceriantheopsis americanus at all stations throughout the study period cannot rule out the alternative that there simply may not have been any microparasites in those anemones at the $200 \mathrm{E}$ station in June and July of 1983, as found in July 1983 at REFS, August 1983 at $100 \mathrm{E}$ and $400 \mathrm{E}$, and March 1984 at 200E. We cannot identify the microparasite at this time (D. J. Alderman, A. Cali, T. C. Cheng, C. A. Farley, S. McGladdery, M Moser, D. Porter, V Sprague, S. J Upton pers. comm.) 
We are also unsure of the interpretation of some of the other unusual conditions encountered in this study, for example the tentacular cysts, black particulate accumulations in the gastrodermis, hypertrophied cells in the lobes of the mesenterial filaments, and spirocystassociated necrosis. The latter condition has been seen rarely in corals (E. C. Peters unpubl.) and may represent a primitive response by pluripotent interstitial cells to toxins produced by parasites. The ovoid basophilic bodies may consist of prokaryotes that are mycoplasmal, chlamydial, rickettsial or bacterial (Otto et al. 1979, Peters et al. 1983), and electron microscopy will be necessary to determine their nature.

The present data confirmed earlier observations that cerianthids are protandrous hermaphrodites. The only cases of abnormal gonad development, necrosis of ova and spermaries, and premature ova extrusion occurred in anemones from the $200 \mathrm{E}$ station following the dredge disposal in June and July of 1983. Hydrocarbon exposure has been linked to adverse effects on gonads in scleractinian corals (see Peters et al. 1981), but again, the BRH dredge spoil disposal may have influenced diet or other factors leading to the observed lesions. Since some portion of the Ceriantheopsis americanus population can spawn year-round, recolonization of disturbed sites may occur rapidly depending on field conditions.

The results of this study suggest an explanation for the earlier observations made from field samplings. Ceriantheopsis americanus is probably sensitive to acute exposures to toxic sediments resulting in its appearance only at the edges of waste sites, although questions remain about the processes by which anemones are affected by the dredge spoil deposition. We do not know whether the improved condition of anemones collected from the $200 \mathrm{E}$ station was due to recovery of normal cell metabolism and repair of lesions with changes in environmental conditions at the station or if there was recolonization and replacement by more pollutionresistant $C$. americanus. Further investigations of bioaccumulation, physiology, and histopathology in this cerianthid and other anthozoans from polluted environments should prove to be valuable in pollution monitoring studies, as they have for other benthic invertebrates (Reish 1972, Bang 1980, Sindermann et al. 1980).

Acknowledgements. The authors thank the staff of the USEPA Environmental Research Laboratory, Narragansett, and particularly M. Casey, M. Redmond, A. Elskus, and L. LeBlanc for collecting the anemones in the field. M. Casey and C. A. Yevich assisted with the histopathological preparations. We also thank $\mathrm{S}$. Pratt for sharing the Ceriantheopsis americanus benthos abundance data. Comments from S. D. Cairns, J. C. Harshbarger, H. B. McCarty, and 3 anonymous reviewers improved the manuscript. ECP was supported by a Smithsonian Institution Postdoctoral Fellowship and a National Research Service Award Training Fellowship (Award Number 1 F32 CA 08327-01 from the National Cancer Institute) during the final preparation of this manuscript.

\section{LITERATURE CITED}

Aller, R. C. (1983). The importance of the diffuse permeability of animal burrow linings in determining marine sediment chemistry. J. mar. Res. 41 299-322

Bang, F. B. (1980). Monitoring pathological changes as they occur in estuaries and in the ocean in order to measure pollution (with special reference to invertebrates). Rapp. P.-v. Réun. Cons. perm. int. Explor. Mer 179: 118-124

Barszcz, C. A., Yevich, P. P. (1975). The use of Helly's fixative for marine invertebrate histopathology. Comp. Pathol. Bull. 7: 4

Caracciolo, J. V., Steimle, F. W., Jr (1983). An atlas of the distibution and abundance of dominant benthic invertebrates in the New York Bight apex with reviews of their life histories. National Oceanographic and Atmospheric Administration Technical Report, National Marine Fisheries Service, SSRF-766

Carlgren, O. (1912). Ceriantharia. Dan. Ingolf-Exped. 5 (3): 1-78

Carigren, O. (1951). Actinaria from North America. Ark. Zool. 3: $373-390$

Couch, J. A., Courtney, L. (1977). Interaction of chemical pollutants and virus in a crustacean: a novel bioassay system. Ann. N.Y Acad. Sci. 298: 497-504

Eleftheriou, A., Basford, D. J. (1983). The general behavior and feeding of Cerianthus lloydi Gosse (Anthozoa, Coelenterata). Cah. Biol. mar. 24: 147-158

Evans, E. C., III (1977). Microcosm responses to environmental perturbants: an extension of baseline field survey. Helgoländer wiss. Meeresunters. 30: 178-191

Farley, C. A. (1977). Neoplasms in estuarine molluscs and approaches to ascertain causes. Ann. N.Y Acad. Sci. 298 : $225-232$

Frey. R. W. (1970). The lebensspuren of some common marine invertebrates near Beaufort, North Carolina. II. Anemone burrows, J. Paleont. 44: 308-311

Gardner, G. R., Yevich, P. P. (1988). Comparative histopathological effects of chemically contaminated sediment on marine organisms. Mar envir. Res. 24: 311-316

Knap, A. H., Solbakken, J. E., Dodge, R. E., Sleeter, T. D., Wyers, S. J., Palmork, K. H. (1983). Accumulation and elimination of $\left(9-{ }^{14} \mathrm{C}\right)$ phenanthrene in the reef-building coral (Diploria strigosa). Bull. envir. Contam. Toxic. 28: 281-284

Lake, J., Hoffman, G. L., Schimmel, S. C. (1985). Bioaccumulation of contaminants from Black Rock Harbor dredged material by mussels and polychaetes. Technical Report D85-2, prepared by the U.S. Environmental Protection Agency, Environmental Research Laboratory, Narragansett, Rhode Island, for the U.S. Army Engineer Waterways Experiment Station. Vicksburg, Mississippi

Loya, Y., Rinkevich, B. (1980). Effects of oil pollution on coral reef communities. Mar. Ecol. Prog. Ser. 3: 167-180

Luna, L. G. (ed.) (1968). Manual of Histologic Techniques of the Armed Forces Institute of Pathology. 3rd ed. McGrawHill, New York

MacLean, S. A., Farley, C. A., Newman, M. W., Rosenfield, A. (1981). Gross and microscopic observations on some biota from Deep Water Dumpsite 106. In: Ketchum, B. H., Kester, D. R., Park, P. K. (eds.) Ocean dumping of industrial wastes. Plenum, New York, p. 421-437

Mariscal, R. N., Bigger, C. H., McLean, R. B. (1976). The form and function of cnidarian spirocysts. I. Ultrastructure of the capsule exterior and relationship to the tentacle sensory surface. Cell. Tissue Res. 168: 465-474

Mariscal, R. N., Conklin, E. J., Bigger, C. H. (1977). The ptychocyst, a major new category of cnida used in tube construction by a cerianthid anemone. Biol. Bull. mar. biol. Lab., Woods Hole 152: 392-405 
Otto, S. V., Harshbarger, J. C., Chang, S. C. (1979), Status of selected unicellular eucaryote pathogens, and prevalence and histopathology of inclusions containing obligate procaryote parasites in commercial bivalve mollusks trom Maryland estuaries. Haliotis, Paris 8: 285-295

Pearce, J. B. (1972). The effects of solid waste disposal on benthic communities in the New York Bight. In: Ruivo, M. (ed.) Marine pollution and sea life. Fishing News (Books) Ltd., London, p. 404-411

Pearce, J. B., Caracciolo, J. V., Halsey, M. B., Rogers, L. H. (1976). Temporal and spatial distributions of benthic macroinvertebrates in the New York Bight. Am. Soc. Limnol. Oceanogr Spec. Symp. 2: 394-403

Pearson, T. H., Rosenberg, R. (1978). Macrobenthic succession in relation to organic enrichment and pollution of the marine environment. Oceanogr mar. Biol. An. Rev. 16: 229-311

Pesch, G. G., Pesch, C. E., Malcolm, A. R., Rogerson, P. F., Gardner, G. R., Mueller, C., Munns, W. R., Jr., Heltshe, J., Lee, T. C., Senelál, A. G. (1985). Sister chromatid exchange in marine polychaetes exposed to Black Rock Harbor sediment. Technical Report D-87-5 prepared by the U.S. Environmental Protection Agency, Narragansett, Rhode Island, for the U.S. Army Engineer Waterways Experiment Station, Vicksburg, Mississippi

Peters, E. C., Meyers, P. A., Yevich, P. P., Blake, N. J. (1981). Bioaccumulation and histopathological effects of oil on a stony coral. Mar. Pollut. Bull. 12: 333-339

Peters, E. C., Oprandy, J. J., Yevich, P. P. (1983). Possible causal agent of 'white band disease' in Caribbean acroporid corals. J. Invertebr. Path. 41: 394-396

Peters, E. C., Pilson, M. E. Q. (1985). A comparative study of the effects of sedimentation on symbiotic and asymbiotic colonies of the coral Astrangia danae Milne Edwards \& Haime 1849. J. exp. mar. Biol. Ecol. 92: 215-230

Reish, D. J. (1972). The use of marine invertebrates as indicators of varying degrees of marine pollution. In: Ruivo, $\mathrm{M}$. (ed.) Marine pollution and sea life. Fishing News (Books) Ltd., London, p. 203-207

Rogerson, P. F., Schimmel, S. C., Hoffman, G. (1985). Chemical and biological characterization of Black Rock Harbor dredged material. Technical Report D-85-9, prepared by the U.S. Environmental Protection Agency. Narragansett, Rhose Island, for the U.S. Army Engineer Waterways Experiment Station, Vicksburg, Mississippi

Sassaman, C., Mangum, C. P. (1974). Gas exchange in a cerianthid. J. exp. Zool. 188: 297-306

Schumacher, H. (1979). Experimentelle Untersuchungen zur Anpassung von Fungiiden (Scleractinia; Fungiidae) an unterschiedliche Sedimentations- und Bodenverhälnisse [Experiments on adaptations to sedimentation and substrate in fungiid corals (Scleractinia; Fungiidae)]. Int. Rev. ges. Hydrobiol. 64: 207-318

Scott, J., Rhoads, D., Rosen, J., Pratt, S., Gentile, J. (1987). Impact of open-water disposal of Black Rock Harbor dredged material on benthic recolonization at the FVP site. Technical Report D-87-4, prepared by the U.S. Environmental Protection Agency, Narragansett, Rhode Island, for the U.S. Army Engineer Waterways Experiment Station, Vicksburg, Mississippi

Sindermann, C. J. (1983). An examination of some relationships between pollution and disease. Rapp. P.-v. Réun. Cons. perm. int. Explor Mer 182: 37-43

Sindermann, C. J., Bang, F. B., Christensen, N. O., Dethlefsen,

Responsible Subject Editor: Dr A. K. Sparks, Seattle, Washington, USA
V., Harshbarger, J. C., Mitchell, J. R., Mulcahy, M. F. (1980). The role and value of pathoblology in pollution effects monitoring programs. Rapp. P-v. Réun. Cons, int. perm. Explor. Mer 179: 135-151

Solbakken, J. E., Knap, A. H., Orr, P. L. (1985). Uptake and elimination of lindane and a phthalate ester in tropical corals and mussels. Mar. envir Res, 16: 103-113

Stebbing, A. R. D. (1979). An experimental approach to the determinants of biological water quality. Phil. Trans. R. Soc. (Ser. B.) 286: 465-481

Steel, R. G. D., Torrie, J. H. (1960). Principles and procedures of statistics. McGraw-Hill, New York

Szmant-Froelich, A., Johnson, V., Hoehn, T., Battey, J., Smith, G. J., Fleischmann, E., Porter, J., Dallmeyer, D. (1981). The physiological effects of oil-drilling muds on the Caribbean coral Montastrea annularis. Proc. 4th int. Symp. coral Reefs 1: 163-168 [Gomez, E. D. et al. (eds.) Marine Sciences Center, University of the Philippines, Quezon City]

Tiffon, Y (1975). Hydrolases dans l'ectoderme de Cerianthus lloydi Gosse, Cerianthus membranaceus Spallanzani et Metridium senile (L.): Mise en evidence d'une digestion extracellulaire et extracorporelle. J. exp. mar. Biol. Ecol. 18: $243-254$

Verrill, A. E. (1864). Revision of the polypi of the eastern coast of the United States. Mem. Boston Soc. nat. Hist. 1. 1-45

Widersten, B. (1976). Ceriantharia, Zoanthidea, Corallimorpharia, and Actinaria from the continental shelf and slope off the eastern coast of the United States. Fish. Bull. U.S. 74: $857-878$

Winstead, J. T., Couch, J. A. (1988). Enhancement of protozoan pathogen Perkinsus marinus infections in American oysters Crassostrea virginica exposed to the chemical carcinogen n-nitrosodiethylamine (DENA). Dis. aquat. Org. 5: 205-213

Yevich, P. P., Barszcz, C. A. (1981). Preparation of aquatic animals for histopathological examination. Biological Field and Laboratory Methods for Measuring the Quality of Surface Waters and Wastes, 2nd Ed. (To be published). Preparation manual printed separately by the Aquatic Biology Section, Biological Methods Branch, Environmental Monitoring and Support Laboratory, U.S. Environmental Protection Agency, Cincinnati, Ohio 45268

Yevich, P. P., Barszcz, C. A. (1983). Hisopathology as a monitor for marine pollution: results of the histopathologic examination of the animals collected for the U.S. 1976 Mussel Watch Program. Rapp. P.-v. Réun. Cons. perm. int. Explor. Mer 182: 96-102

Yevich, P. P., Yevich, C., Pesch, G., Nelson, W. (1987). Effects of Black Rock Harbor dredged material. on the histopathology of the blue mussel Mytilus edulis and polychaete worm Nephtys incisa after laboratory and field exposures. Technical Report D-87-8, prepared by the U.S. Environmental Protection Agency, Narragansett, Rhode Island, for the U.S. Army Engineer Waterways Experiment Station, Vicksburg, Mississippi

Yevich, P. P., Yevich, C. A., Scott, K. J., Redmond, M., Black, D. Schauer, P. S., Pesch, C. E. (1986). Histopathological effects of Black Rock Harbor dredged material on marine organisms: a laboratory investigation. Technical Report D86-1. prepared by the U.S. Environmental Protection Agency, Environmental Research Laboratory, Narragansett, Rhode Island, for the U.S. Army Engineer Waterways Experiment Station, Vicksburg, Mississippi

Manuscript first received: June, 17, 1988

Revised version accepted: July 20, 1989 